\title{
The Possible Role of the Uropygial Gland on Mate Choice in Domestic Chicken
}

\author{
Atsushi Hirao \\ Division of Anatomy \& Embryology, Department of Anatomy, School of Medicine, Jichi Medical University, Shimotsuke, \\ Tochigi 329-0498, Japan \\ Correspondence should be addressed to Atsushi Hirao, jhirao@jichi.ac.jp
}

Received 30 January 2011; Accepted 14 May 2011

Academic Editor: Hynek Burda

Copyright ( $(2011$ Atsushi Hirao. This is an open access article distributed under the Creative Commons Attribution License, which permits unrestricted use, distribution, and reproduction in any medium, provided the original work is properly cited.

In avian mating systems, male domestic fowls are polygamous and mate with a number of selected members of the opposite sex. The factors that influence mating preference are considered to be visual cues. However, several studies have indicated that chemosensory cues also affect socio-sexual behavior, including mate choice and individual recognition. The female uropygial gland appears to provide odor for mate choice, as uropygial gland secretions are specific to individual body odor. Chicken olfactory bulbs possess efferent projections to the nucleus taeniae that are involved in copulatory behavior. From various reports, it appears that the uropygial gland has the potential to act as the source of social odor cues that dictate mate choice. In this review, evidence for the possible role of the uropygial gland on mate choice in domestic chickens is presented. However, it remains unclear whether a relationship exists between the uropygial gland and major histocompatibility complex-dependent mate choice.

\section{Introduction}

Nearly all mammals emit chemical substances into their surroundings and these substances have important effects on mating behavior. For example, male house mice (Mus musculus) scent mark with urine to attract females for mating. Additionally, female mice are able to distinguish between the odors of parasitized and unparasitized males and are attracted to the odor of the latter [1-3]. It appears the odors that these mating preferences evoke can be attributed to the major histocompatibility complex (MHC) [4].

In contrast to mammals, and as avian species have often been classified as anosmic or microsmatic [5-9], olfactory information is generally not considered to be involved in the mating behavior of birds. However, several investigators have suggested that chemical cues, such as individual recognition and mate choice, affect avian social behavior $[5-8,10,11]$. In addition, the Blue Tit (Cyanistes caeruleus L.) can detect chemical secretions of predators and exhibit antipredatory behavior to reduce the risk of predation [12]. More recently, it has been reported that the female chicken (Gallus gallus domesticus) uropygial gland is related to male mate choice [13]. Mate choice is defined as any pattern of behavior, shown by members of one sex, which leads to them being more likely to mate with certain members of the opposite sex than with others [14].

The three aims of this review are to present the factors that evoke mate choice in domestic chickens, examine the possible role of the chicken uropygial gland as a source of social odor cues, and discuss whether uropygial gland secretions affect MHC-dependent mate choice.

\section{What Signals Elicit Mate Choice in Domestic Chickens?}

Mating behavior in domestic chickens has been described in detail by previous investigators [15]. Prior to mating, a series of courtship displays take place before mating based on a stimulus-response sequence initiated by males (Figure 1). Furthermore, several researchers have provided supporting evidence that domestic fowls exhibit non-random mating [16-18].

In domestic fowls, vision appears to play a central role in mating behavior $[19,20]$. As the size of sexual ornaments, such as combs, wattles, and spurs are under the control of 


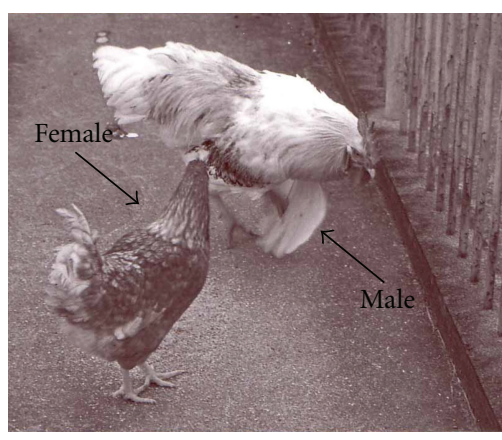

(a)

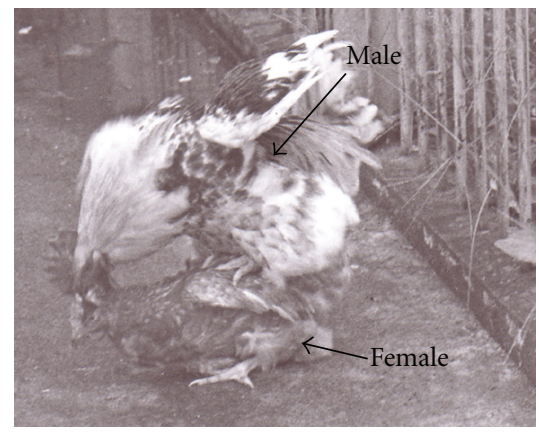

(b)

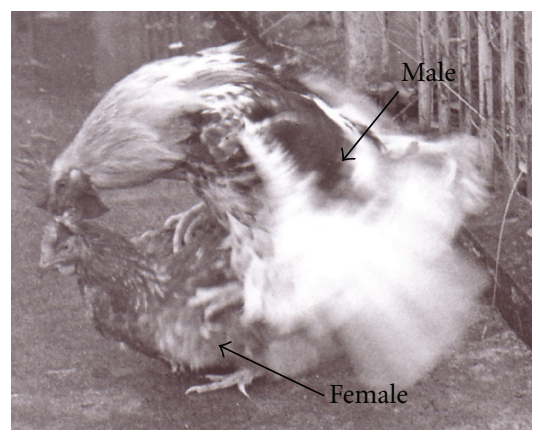

(c)

Figure 1: Photographs of sexual behavior exhibited by domestic chickens. (a) Courtship waltzing, (b) mounting, and (c) copulation.

testosterone [21], these ornaments are regarded as signals affecting mate choice. Zuk et al. [22] and Johnsen and Zuk [23] suggested that longer, redder combs in male red jungle fowls (Gallus gallus) were preferred by females of the species. Graves et al. [24] also reported that male chickens having lager combs were selected more often by female birds. A recent study on male wattles reported that male wattle size significantly reduces orienting latency in tidbitting display [25]. From these reports, the comb and wattle size of male chickens and red jungle fowls appears to act as a dominant signal influencing mate selection by female birds.

On the other hand, there is little evidence that chemical signals are involved in mate choice in domestic chickens. Recently, however, it has been further suggested that the female uropygial gland provides an olfactory cue mediating mate choice. For instance, male domestic chickens mate significantly more with female birds possessing uropygial glands than with uropygial-glandectomized females [13]. Additionally, this mate preference disappeared in males subjected to olfactory sensory deprivation [13]. Thus, to investigate secretions from the uropygial gland as the source of odor cues merits further study.

\section{Is the Chicken Uropygial Gland a Source of Social Odor?}

Avian species with scent glands that emit strong odors are rarely observed. Thus, it is generally considered that birds do not use chemical information in mating behavior. However, birds possess the relatively large uropygial gland at the base of their tail feathers (Figure 2) [9, 26-28] which produces a large amount of volatile and nonvolatile compounds in the form of a waxy fluid that is spread on feathers as a part of plumage maintenance [9, 26-28]. Furthermore, volatile compounds in uropygial gland secretions exhibit seasonal changes [29-32]. A few recent studies have suggested that gland secretions include socio-ecological information, which allows distinction of species, gender, and even individuals $[33,34]$. Moreover, several reports have shown that volatile compounds in uropygial gland secretions are responsible for odors with specific functions $[32,35,36]$. For example, the gland secretions of some birds contain volatile compounds that contribute to an unpleasant odor emitted to aid in the escape from predators [37]. Taken together, these reports suggest that volatile compounds in uropygial gland secretions act as chemical cues, and may reflect the social status of birds.

In the case of domestic chickens, uropygial gland secretions rarely contain waxes [28], which are fundamental to waterproofing and maintaining the flexibility of feathers [28]. This finding suggests that the secretions possess another function besides waterproofing. Indeed, the red jungle fowl emits an individual body odor that is produced by aliphatic carboxylic acids [38]. Moreover, trained mice are able to discriminate between these odors at the level of the individual [38]. Based on this evidence, chicken uropygial gland secretions have the potential to function as social odor cues.

\section{Utilization of Olfactory Cues for Mating Systems in Domestic Chicken}

In contrast to previous works on avian olfactory function, electrophysiological studies have provided evidence that domestic fowls are indeed capable of perceiving odor cues. For example, chicken olfactory bulbs respond to odor stimuli $[39,40]$. In addition, an in situ hybridization study revealed that a number of olfactory receptor genes have been characterized in the olfactory epithelium [41]. Recently, a second class within the odorant receptor family, termed trace amine-associated receptors (TAARs), was identified. Certain mouse TAARs are able to perceive volatile amines present in urine, and one TAAR was found that recognizes a pheromone compound $[42,43]$. From these results, it is suggested that one function of TAARs involves the detection of social cues [42, 43]. Moreover, database searches have revealed that domestic chickens possess three functional TAAR genes [44], and a protein sequence of chicken TAARs has also been determined [45]. More recently, Gomez and Celii [46] have established a culture method of olfactory sensory neurons, which is a powerful tool for in vitro studies aimed at understanding olfactory perception in domestic chickens.

Olfactory bulbs of domestic chickens are innervated by efferent fibers [47] and possess similar projection sites to that of other birds [48-50]. Moreover, chicken olfactory 


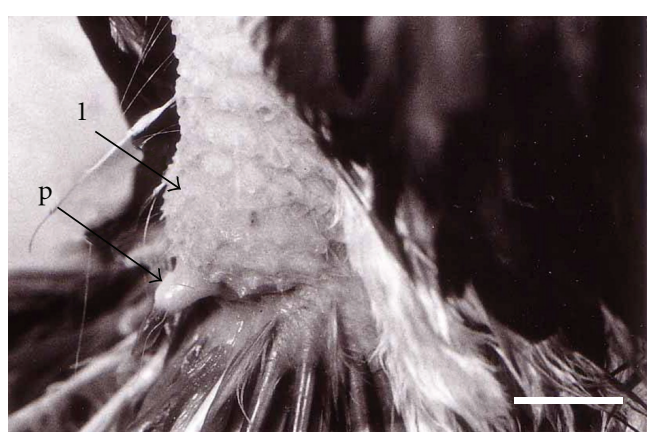

(a)

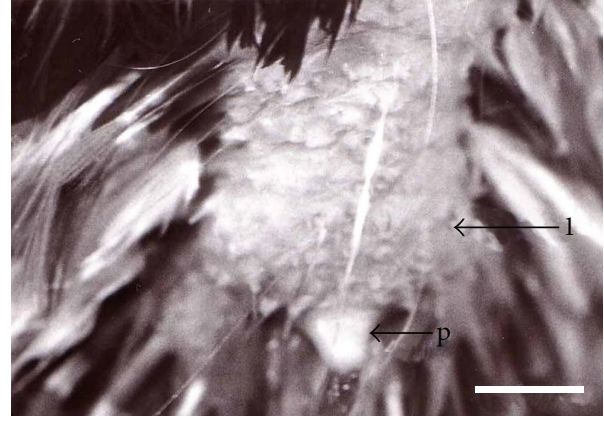

(b)

FIGURE 2: Photographs of the domestic chicken uropygial gland. (a) Lateral and (b) dorsal view of an adult uropygial gland. l: lobe, p: papilla. Scale bars indicate $1 \mathrm{~cm}$.

bulbs project to the nucleus taeniae [47]. In Japanese quail (Coturnix japonica), a lesion of this nucleus causes a significant reduction in the frequency of copulation [51]. Based on these findings, domestic chickens appear to possess functional olfactory systems that influence mating behavior.

Behavioral investigations have also demonstrated that domestic chickens react to various olfactory stimuli [52]. It seems that chemical information plays an important role for their life. However, the direct evidence that domestic chicken might use chemosensory cues to assess mating behavior is rarely reported. In other birds, such as mallard ducks (Anas platyrhynchos), bilateral olfactory nerve sectioning significantly reduced the number of social and mating behavior [53]. In Japanese quail, bilateral nostril sealing decreased the number of mating behavior $[6,54]$. To understand the role of olfaction in mating behavior, it is at least necessary to perform similar experiments in domestic chickens.

\section{Is MHC-Dependent Mate Choice in Chickens Mediated by the Uropygial Gland?}

In mice, MHC-based mate selection is proposed to involve the detection of male odors by females that leads to mating with males carrying dissimilar MHC genes, and results in progeny with disease-resistance genes [55-60]. In avian species, although a few investigators have suggested that mate choice might be affected by olfaction [32, 61, 62], there is little evidence for the direct relation between MHCdependent mate choice and the uropygial gland.

However, recent studies suggest the possibility that MHC genes are related to mate choice in birds. According to research of outbred populations, house sparrows (Passer domesticus) appear to exhibit MHC-based mate choice [63]. Moreover, female house sparrows seem to utilize olfactory cues for MHC-dependent mating preference [64]. Male red jungle fowls show several cryptic preferences by allocating additional sperm to MHC-dissimilar females [65]. Additionally, it has been shown in several bird species that uropygial gland size changes with the load of feather mites, bacteria, and chewing lice [66-68], while removal of the uropygial gland leads to increased levels of fungi and featherdegrading bacteria on feathers, and higher levels of feather degradation [28]. These findings are supported by a study that demonstrated that chicken uropygial gland secretions reduce the levels of these microorganisms on feathers [69]. Taken together, these reports suggest that chemical defenses provided by the uropygial gland may reflect the status of disease-resistance. It is assumed that uropygial gland secretions contain MHC proteins. Unfortunately, this possibility has not been explored. The issue should be examined to understand MHC-dependent mate choice in domestic chickens.

\section{Conclusions and Future Work}

It is known that male domestic chickens prefer to mate with certain members of the opposite sex, with previous works suggesting that visual cues play a central role in mating behavior. Undoubtedly, domestic chickens depend predominantly on visual information to function, while olfaction appears to play a role in their life. Chemical cues from the uropygial gland may compensate for information that vision is not able to detect.

Finally, future investigations on the uropygial gland and mate choice in domestic chickens should consider two important issues. Firstly, although MHC genes heavily affect mate choice [4] in mammals through olfaction, it remains unclear whether uropygial gland secretions contain MHC proteins. Resolving this issue is necessary to understand mate choice in domestic chickens. Secondly, the localization of olfactory receptors which are able to perceive social odor cues has not been examined. For instance, mouse V2 receptors are able to perceive odor substances in urine and therefore play an important role in MHC-dependent mate choice [4]. To determine the localization of such olfactory receptors in domestic chickens, it is first necessary to elucidate the mechanisms of perceiving social odor.

\section{References}

[1] M. Kavaliers and D. D. Colwell, "Aversive responses of female mice to the odors of parasitized males: neuromodulatory mechanisms and implications for mate choice," Ethology, vol. 95, no. 3, pp. 202-212, 1992. 
[2] M. Kavaliers and D. D. Colwell, "Discrimination by female mice between the odours of parasitized and non-parasitized males," Proceedings of the Royal Society of B, vol. 261, no. 1360, pp. 31-35, 1995.

[3] M. Kavaliers and D. D. Colwell, "Odours of parasitized males induce aversive responses in female mice," Animal Behaviour, vol. 50, no. 5, pp. 1161-1169, 1995.

[4] P. A. Brennan and K. M. Kendrick, "Mammalian social odours: attraction and individual recognition," Philosophical transactions of the Royal Society of London. Series B, Biological sciences, vol. 361, no. 1476, pp. 2061-2078, 2006.

[5] S. P. Caro and J. Balthazart, "Pheromones in birds: myth or reality?" Journal of Comparative Physiology A, vol. 196, no. 10, pp. 751-766, 2010.

[6] J. Balthazart and M. Taziaux, "The underestimated role of olfaction in avian reproduction?" Behavioural Brain Research, vol. 200, no. 2, pp. 248-259, 2009.

[7] J. C. Hagelin and I. L. Jones, "Bird odors and other chemical substances: a defense mechanism or overlooked mode of intraspecific communication?” Auk, vol. 124, no. 3, pp. 741761, 2007.

[8] J. C. Hagelin, "Odors and chemical signaling," in Reproductive Behavior and Phylogeny of Birds, B. G. M. Jamieson, Ed., pp. 76-119, Science Publishers, New Hampshire, NY, USA, 2007.

[9] T. J. Roper, "Olfaction in birds," in Advances in the Study of Behavior, P. J. B. Slater, J. S. Rosenblat, C. T. Snowden, and T. J. Roper, Eds., pp. 247-332, Academic Press, Boston, NY, USA, 1999.

[10] F. Bonadonna, "Olfaction in petrels from homing to self-odor avoidance," Annals of the New York Academy of Sciences, vol. 1170, pp. 428-433, 2009.

[11] T. W. O’Dwyer and G. A. Nevitt, “Individual odor recognition in procellariiform chicks: potential role for the major histocompatibility complex," Annals of the New York Academy of Sciences, vol. 1170, pp. 442-446, 2009.

[12] L. Amo, I. Galvan, G. Tomas, and J. J. Sanz, "Predator odour recognition and avoidance in a songbird," Functional Ecology, vol. 22, pp. 289-293, 2008.

[13] A. Hirao, M. Aoyama, and S. Sugita, "The role of uropygial gland on sexual behavior in domestic chicken Gallus gallus domesticus," Behavioural Processes, vol. 80, no. 2, pp. 115-120, 2009.

[14] T. R. Halliday, "The study of mate choice," in Mate Choice, P. Bateson, Ed., pp. 3-32, Cambridge University Press, Cambridge, UK, 1983.

[15] A. M. Guhl and G. Fischer, "The behaviour of chickens," in The Behaviour of Domestic Animals, E. S. E. Hafez, Ed., pp. 515553, Baillère Tindall, London, UK, 1975.

[16] C. W. Upp, "Preferential mating in fowls," Poultry Science, vol. 7, pp. 225-232, 1928.

[17] A. M. Guhl, "Measurable differences in mating behaviour of cocks," Poultry Science, vol. 30, pp. 687-693, 1951.

[18] A. Lill, "Some observations on social organisation and non-random mating in captive Burmese red jungle fowl," Behaviour, vol. 26, pp. 228-242, 1966.

[19] E. K. M. Jones, N. B. Prescott, P. Cook, R. P. White, and C. M. Wathes, "Ultraviolet light and mating behaviour in domestic broiler breeders," British Poultry Science, vol. 42, no. 1, pp. 23 32, 2001.

[20] E. K. M. Jones and N. B. Prescott, "Visual cues used in the choice of mate by fowl and their potential importance for the breeder industry," World's Poultry Science Journal, vol. 56, no. 2, pp. 128-138, 2000.
[21] A. B. Gilbert, "The endocrine ovary in reproduction," in Physiology and Biochemistry of the Domestic Fowl, D. J. Bell and B. M. Freeman, Eds., pp. 1449-1468, Academic Press, London, UK, 1971.

[22] M. Zuk, T. S. Johnsen, and T. MacLarty, "Endocrine-immune interactions, ornaments and mate choice in red jungle fowl," Proceedings of the Royal Society of B, vol. 260, no. 1358, pp. 205-210, 1995.

[23] T. S. Johnsen and M. Zuk, "Repeatability of mate choice in female red jungle fowl," Behavioral Ecology, vol. 7, no. 3, pp. 243-246, 1996.

[24] H. B. Graves, C. P. Hable, and T. H. Jenkins, "Sexual selection in gallus: effects of morphology and dominance on female spatial behavior," Behavioural Processes, vol. 11, no. 2, pp. 189197, 1985.

[25] C. L. Smith, D. A. Van Dyk, P. W. Taylor, and C. S. Evans, "On the function of an enigmatic ornament: wattles increase the conspicuousness of visual displays in male fowl," Animal Behaviour, vol. 78, no. 6, pp. 1433-1440, 2009.

[26] A. Salibian and D. Montalti, "Physiological and biochemical aspects of the avian uropygial gland," Brazilian Journal of Biology, vol. 69, no. 2, pp. 437-446, 2009.

[27] J. Jacob, "Uropygial gland secretion and feather wax," in Chemical Zoology, A. H. Brush, Ed., pp. 165-211, Academic Press, London, UK, 1978.

[28] J. Jacob and V. Ziswiler, "The uropygial gland," in Avian Biology, D. S. Frander, J. R. King, and K. C. Parks, Eds., pp. 199-324, Academic Press, New York, NY, USA, 1982.

[29] J. Jacob, J. Balthazart, and E. Schoffeniels, "Sex differences in the chemical composition of uropygial gland waxes in domestic ducks," Biochemical Systematics and Ecology, vol. 7, no. 2, pp. 149-153, 1978.

[30] T. Piersma, M. Dekker, and J. S. Sinninghe Damsté, "An avian equivalent of make-up?” Ecology Letters, vol. 2, no. 4, pp. 201203, 1999.

[31] J. Reneerkens, T. Piersma, and J. S. Sinninghe Damsté, "Sandpipers (Scolopacidae) switch from monoester to diester preen waxes during courtship and incubation, but why?" Proceedings of the Royal Society of B, vol. 269, no. 1505, pp. 2135-2139, 2002.

[32] H. A. Soini, S. E. Schrock, K. E. Bruce, D. Wiesler, E. D. Ketterson, and M. V. Novotny, "Seasonal variation in volatile compound profiles of preen gland secretions of the dark-eyed junco (Junco hyemalis)," Journal of Chemical Ecology, vol. 33, no. 1, pp. 183-198, 2007.

[33] J. Mardon, S. M. Saunders, M. J. Anderson, C. Couchoux, and F. Bonadonna, "Species, gender, and identity: cracking petrels' sociochemical code," Chemical Senses, vol. 35, no. 4, pp. 309$321,2010$.

[34] D. J. Whittaker, H. A. Soini, J. W. Atwell, C. Hollars, M. V. Novotny, and E. D. Ketterson, "Songbird chemosignals: volatile compounds in preen gland secretions vary among individuals, sexes, and populations," Behavioral Ecology, vol. 21, no. 3, pp. 608-614, 2010.

[35] M. Haribal, A. Dhondt, and E. Rodriguez, "Diversity in chemical compositions of preen gland secretions of tropical birds," Biochemical Systematics and Ecology, vol. 37, no. 2, pp. 80-90, 2009.

[36] M. Haribal, A. A. Dhondt, D. Rosane, and E. Rodriguez, "Chemistry of preen gland secretions of passerines: different pathways to same goal? why?" Chemoecology, vol. 15, no. 4, pp. 251-260, 2005.

[37] B. V. Burger, B. Reiter, O. Borzyk, and M. A. Du Plessis, "Avian exocrine secretions. I. Chemical characterization of the volatile 
fraction of the uropygial secretion of the green woodhoopoe, Phoeniculus purpureus," Journal of Chemical Ecology, vol. 30, no. 8, pp. 1603-1611, 2004.

[38] A. C. Karlsson, P. Jensen, M. Elgland et al., "Red junglefowl have individual body odors," Journal of Experimental Biology, vol. 213, no. 10, pp. 1619-1624, 2010.

[39] D. E. F. McKeegan and N. Lippens, "Adaptation responses of single avian olfactory bulb neurones," Neuroscience Letters, vol. 344, no. 2, pp. 83-86, 2003.

[40] T. Oosawa, Y. Hirano, and K. Tonosaki, "Electroencephalographic study of odor responses in the domestic fowl," Physiology and Behavior, vol. 71, no. 1-2, pp. 203-205, 2000.

[41] M. Leibovici, F. Lapointe, P. Aletta, and C. Ayer-Le Lièvre, "Avian olfactory receptors: differentiation of olfactory neurons under normal and experimental conditions," Developmental Biology, vol. 175, no. 1, pp. 118-131, 1996.

[42] S. D. Liberles and L. B. Buck, "A second class of chemosensory receptors in the olfactory epithelium," Nature, vol. 442, no. 7103, pp. 645-650, 2006.

[43] S. D. Liberles, "Trace amine-associated receptors are olfactory receptors in vertebrates," Annals of the New York Academy of Sciences, vol. 1170, pp. 168-172, 2009.

[44] Y. Hashiguchi and M. Nishida, "Evolution of trace amineassociated receptor (TAAR) gene family in vertebrates: lineage-specific expansions and degradations of a second class of vertebrate chemosensory receptors expressed in the olfactory epithelium," Molecular Biology and Evolution, vol. 24, no. 9, pp. 2099-2107, 2007.

[45] J. C. Mueller, S. Steiger, A. E. Fidler, and B. Kempenaers, "Biogenic trace amine-associated receptors (TAARs) are encoded in avian genomes: evidence and possible implications," Journal of Heredity, vol. 99, no. 2, pp. 174-176, 2008.

[46] G. Gomez and A. Celii, "The peripheral olfactory system of the domestic chicken: physiology and development," Brain Research Bulletin, vol. 76, no. 3, pp. 208-216, 2008.

[47] A. Hirao, S. Sugita, and K. Sugahara, "Efferent and afferent connections and efferent pathway of olfactory bulb in the chicken (Gallus domesticus)," Animal Science Journal, vol. 71, pp. J483-J490, 2000 (Japanese).

[48] P. Ebinger, G. Rehkamper, and H. Schroder, "Forebrain specialization and the olfactory system in anseriform birds. An architectonic and tracing study," Cell and Tissue Research, vol. 268, no. 1, pp. 81-90, 1992.

[49] A. Reiner and H. J. Karten, "Comparison of olfactory bulb projections in pigeons and turtles," Brain, Behavior and Evolution, vol. 27, no. 1, pp. 11-27, 1985.

[50] G. K. Rieke and B. M. Wenzel, "Forebrain projections of the pigeon olfactory bulb," Journal of Morphology, vol. 158, no. 1, pp. 41-55, 1978.

[51] R. R. Thompson, J. L. Goodson, M. G. Ruscio, and E. AdkinsRegan, "Role of the Archistriatal Nucleus taeniae in the Sexual Behavior of Male Japanese Quail (Coturnix japonica): a Comparison of Function with the Medial Nucleus of the Amygdala in Mammals," Brain, Behavior and Evolution, vol. 51, no. 4, pp. 215-229, 1998.

[52] R. B. Jones and T. J. Roper, "Olfaction in the domestic fowl: a critical review," Physiology and Behavior, vol. 62, no. 5, pp. 1009-1018, 1997.

[53] J. Balthazart and E. Schoffeniels, "Pheromones are involved in the control of sexual behaviour in birds," Naturwissenschaften, vol. 66, no. 1, pp. 55-56, 1979.

[54] M. Taziaux, M. Keller, G. F. Ball, and J. Balthazart, "Sitespecific effects of anosmia and cloacal gland anesthesia on Fos expression induced in male quail brain by sexual behavior," Behavioural Brain Research, vol. 194, no. 1, pp. 52-65, 2008.

[55] K. Yamazaki, E. A. Boyse, V. Mike et al., "Control of mating preferences in mice by genes in the major histocompatibility complex," Journal of Experimental Medicine, vol. 144, no. 5, pp. 1324-1335, 1976.

[56] K. Yamazaki, G. K. Beauchamp, D. Kupniewski, J. Bard, L. Thomas, and E. A. Boyse, "Familial imprinting determines $\mathrm{H}$ 2 selective mating preferences," Science, vol. 240, no. 4857, pp. 1331-1332, 1988.

[57] D. J. Penn, "The scent of genetic compatibility: sexual selection and the major histocompatibility complex," Ethology, vol. 108, no. 1, pp. 1-21, 2002.

[58] D. Penn and W. Potts, "MHC-disassortative mating preferences reversed by cross-fostering," Proceedings of the Royal Society of B, vol. 265, no. 1403, pp. 1299-1306, 1998.

[59] W. K. Potts, C. J. Manning, and E. K. Wakeland, "Mating patterns in seminatural populations of mice influenced by MHC genotype," Nature, vol. 352, no. 6336, pp. 619-621, 1991.

[60] C. R. Freeman-Gallant, M. Meguerdichian, N. T. Wheelwright, and S. V. Sollecito, "Social pairing and female mating fidelity predicted by restriction fragment length polymorphism similarity at the major histocompatibility complex in a song bird," Molecular Ecology, vol. 12, no. 11, pp. 3077-3083, 2003.

[61] F. Bonadonna and G. A. Nevitt, "Partner-specific odor recognition in an antarctic seabird," Science, vol. 306, no. 5697, p. 835, 2004.

[62] B. Zelano and S. V. Edwards, "An Mhc component to kin recognition and mate choice in birds: predictions, progress, and prospects," American Naturalist, vol. 160, no. 6, pp. S225S237, 2002.

[63] C. Bonneaud, O. Chastel, P. Federici, H. Westerdahl, and G. Sorci, "Complex Mhc-based mate choice in a wild passerine," Proceedings of the Royal Society of B, vol. 273, no. 1590, pp. 1111-1116, 2006.

[64] M. Griggio, C. Biard, D. J. Penn, and H. Hoi, "Female house sparrows "count on" male genes: experimental evidence for MHC-dependent mate preference in birds," BMC Evolutionary Biology, vol. 11, no. 1, article 44, 2011.

[65] M. A. F. Gillingham, D. S. Richardson, H. Løvlie, A. Moynihan, K. Worley, and T. Pizzari, "Cryptic preference for MHCdissimilar females in male red junglefowl, Gallus gallus," Proceedings of the Royal Society of B, vol. 276, no. 1659, pp. 1083-1092, 2009.

[66] I. Galván, E. Barba, R. Piculo et al., "Feather mites and birds: an interaction mediated by uropygial gland size?" Journal of Evolutionary Biology, vol. 21, no. 1, pp. 133-144, 2008.

[67] A. P. Møller, G. A. Czirjak, and P. Heeb, "Feather microorganisms and uropygial antimicrobial defences in a colonial passerine bird," Functional Ecology, vol. 23, no. 6, pp. 1097$1102,2009$.

[68] G. Moreno-Rueda, "Uropygial gland size correlates with feather holes, body condition and wingbar size in the house sparrow Passer domesticus," Journal of Avian Biology, vol. 41, no. 3, pp. 229-236, 2010.

[69] A. Bandyopadhyay and S. P. Bhattacharyya, "Influence of fowl uropygial gland and its secretory lipid components on the growth of skin surface fungi of fowl," Indian Journal of Experimental Biology, vol. 37, no. 12, pp. 1218-1222, 1999. 

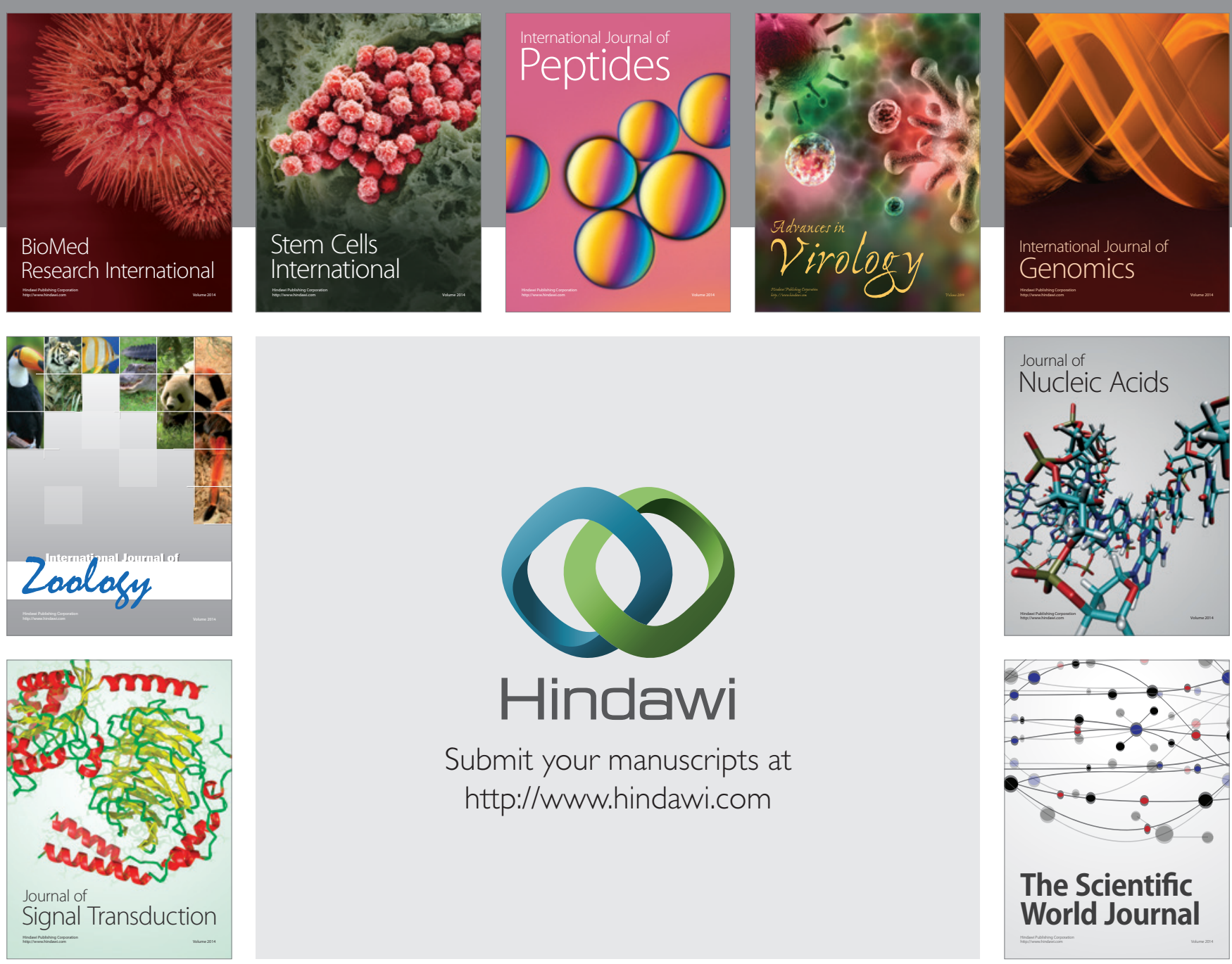

Submit your manuscripts at

http://www.hindawi.com
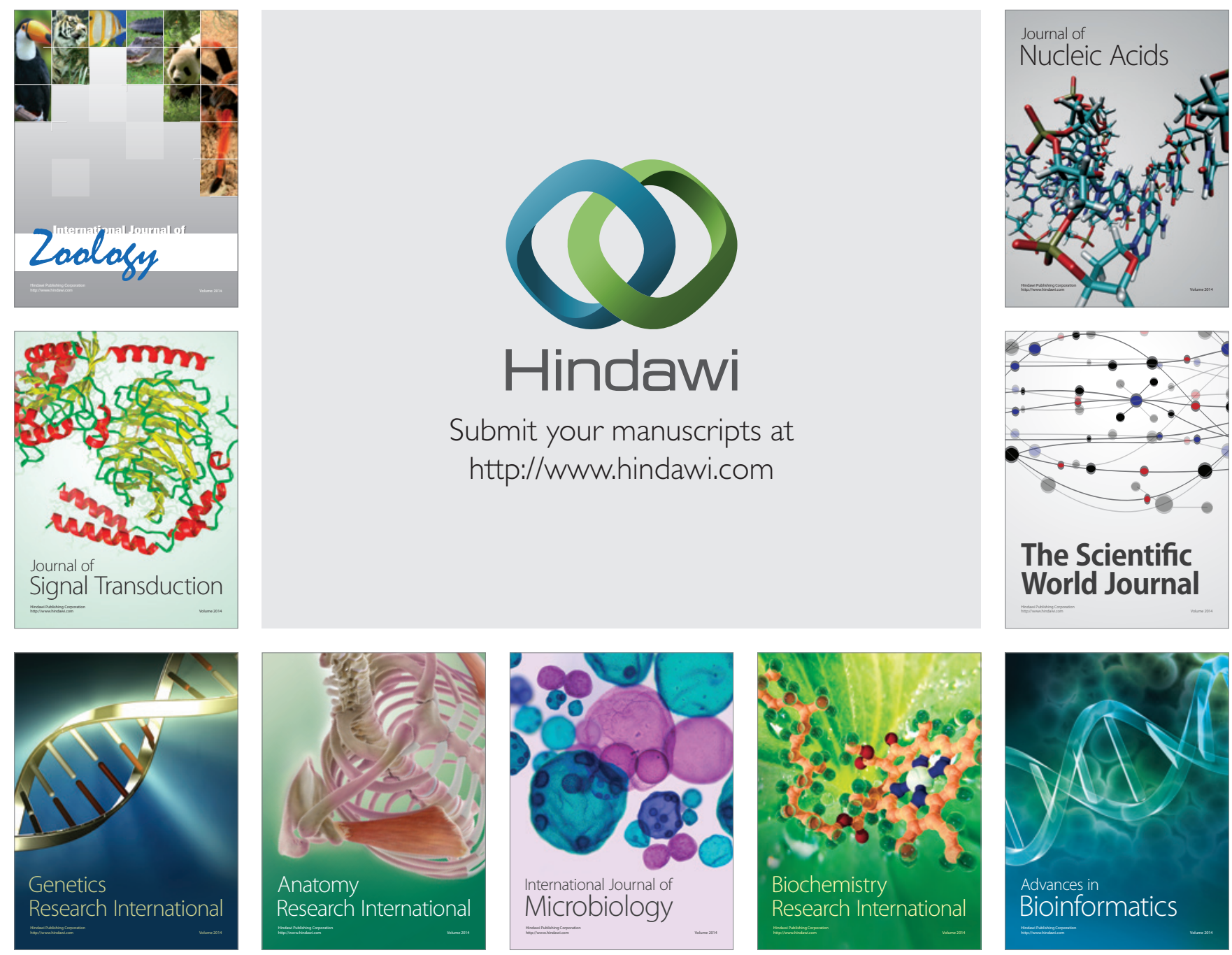

The Scientific World Journal
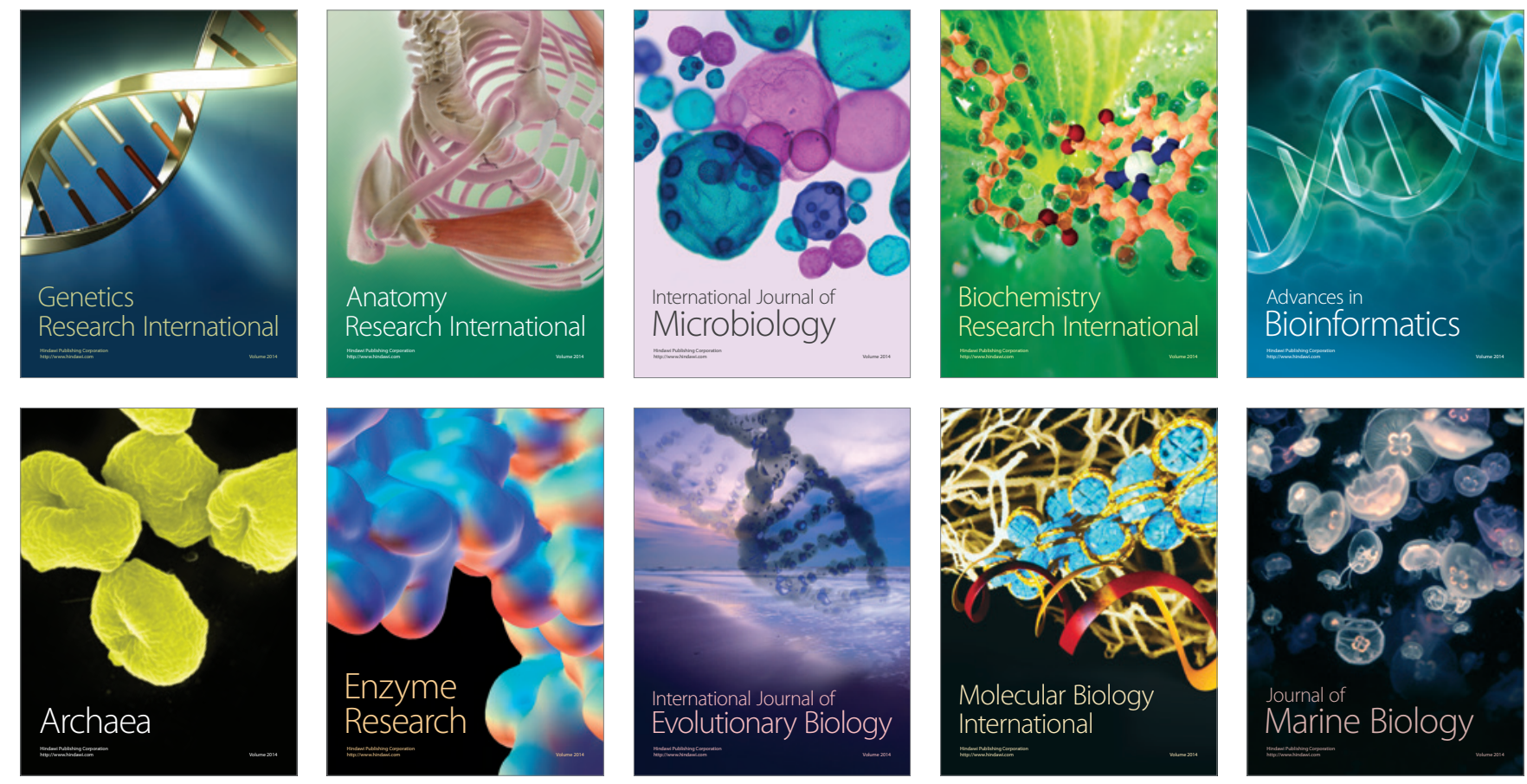